\title{
Determinantion of visitors' willingness to pay to enter Karagol Natural Park of Ankara, Turkey
}

\section{Coskun Serefoglu ${ }^{1^{*}}$}

'Business Development and Strategy Unit, Ankara Development Agency, Asagi Ovecler Mah., 1322, Cadde, N 11, Cankaya, Ankara, Turkey. E-mail: cserefoglu@gmail.com. "Corresponding author.

\begin{abstract}
The objectives of this study were to assess visitors'attitudes, if visitors would be willing to pay to enter Lake Karagol, and what factors affect their decision to pay. The contingent valuation method was used to estimate the economic value of the lake by assessing willingness to pay (WTP). Double dichotomous questions were used in the survey. Respondents were first asked whether or not they would be willing to pay the starting bid. They could either answer in the affirmative (that is, accepted bid) or in the negative (that is, reject the starting bid). The average WTP for an entrance fee was found to be about USD 0.22 for all observations when zero bids were included, and about USD 4.40 when zero bids were excluded. Result of the probit model showed that respondents with a higher income, respondents who were young, and the working status of the respondents had significant impacts on the probability of the WTP. Key words: Double dichotomous bid; Probit model, Contingent Valuation; Natural park; WTP.
\end{abstract}

Determinantes para a "vontade de pagar" dos visitantes do Parque Natural Karagol de Ancara, Turquia

RESUMO: O objetivo deste estudo foi analisar as atitudes dos visitantes e se eles estavam dispostos a pagar entrada no Lago Karago e quais eram os fatores que afetavam a sua decisão. O método de avaliação contingente foi usado para estimar o valor econômico do Lago usando a decisão dos visitantes de estarem dispostos a pagar entrada. Perguntas duplamente dicotômicas foram usadas no questionário. Os inquiridos foram questionados primeiro se estariam dispostos a pagar um valor inicial. Eles poderiam responder afirmativamente (aceitavam o valor) ou negativamente (rejeitavam o valor). O valor médio (vontade de pagar) de uma entrada foi de 0.22 dólares estadunidenses para todas as respostas, incluindo o mínimo de 0 e de 4.40 dólares estadunidenses excluindo o mínimo de 0 . O resultado do modelo de lucro mostrou que os inquiridos com maior valor salarial e mais jovens com estatuto de trabalhadores tinham mais impacto na probabilidade de vontade de pagar. Palavras-chave: Valores duplamente dicotômicos; Área protegida; Parque Natural; Turismo; Vontade de pagar.

\section{INTRODUCTION}

Discussions about charging an entrance fee for national parks are on the agenda of local authorities. While some implement an entrance fee, others are unwilling to charge visitors to enter national parks. That decision is, to some extent, related to the ownership of national parks. National parks in Turkey are generally run by the Regional Directorates of Forestry and Water Affairs. In some cases, the management of parks could be temporarily tendered to private entrepreneurs. Lake Karagol, after being run by private entrepreneurs, was handed over to the Great Municipality of Ankara since 2016. The previous private entrepreneurs who ran the lake charged an entrance fee for the park; however, no entry fee is currently being applied by the Municipality.
Using the contingent valuation method (CVM), information is used to understand how willing people are to pay in certain hypothetical situations that are contingent on being in the actual situation (WHITEHEAD \& BLOMQUIST, 2001). It was argued by CUMMINGS et al (1986) that the CVM has several advantages. First, it provides information with respect to the characteristics of respondents. Second, it uses primary data rather than secondary data, which are created for different purposes. Last, the CVM may have the highest validity when the hypothetical scenario is similar to a familiar market choice situation, as was the case for the model that we will build in the present study. Thus, our research is principally based on the CVM. The questionnaire for the in-person interviews was carefully designed to minimize biases associated with CVM, according to the cautions made by the 
National Oceanic and Atmospheric Administration (NOAA) (ARROW et al., 1993).

Closed-ended questions were used in the present survey because they are well accepted in the literature. HANEMANN (1994) also reported that openended questions were found by respondents to be difficult.

The present paper begins with a short literature review that describes similar studies from other regions. Next, the study methods are described, followed by a results section and a discussion section. The paper ends with a short conclusion.

History of charging fees at parks in the United States dates back to the early 1900s (LINDBERG, 2001). REYNISDOTTIR et al. (2008) reported that there was not a long tradition of charging visitors in Nordic countries, in contrast to the United States and Canada. In developing countries, entry fees for protected areas can be a good source of income (PETERS, 1998). Charging an entry fee to enter national parks might be more acceptable to visitors if the collected fee is dedicated to the improvement of conservation work and to visitor facilities (PETERS, 1998; TISDELL \& WILSON, 2003; TAO, et.al., 2012; BRUNER et al., 2015). However, entry fees might be seen as double charging by some citizens, as they already pay an environmental tax, which may reduce the number of people who visit (ADAMS et al., 1989; MCCARVILLE et al., 1996; STEVENS et al., 1989; SCHWARTZ \& LIN, 2006). SCHULTZ et al. (1998) pointed out that generating revenues to cover costs, as well as providing quality service for the visitors and reducing congestion in over-crowded parks, justifies charging fees for parks. Some factors that influence WTP have been highlighted by LINDBERG (1991), for example, age, education level, and income; the desire to see, visit, and protect a particular park; and fulfilment of expectations. Whether someone is a firsttime visitors and perceptions about environmental concern also affect WTP (REYNISDOTTIR et al., 2008). AHMED and HUSSAIN (2016) reported a positive relationship between the number of visits and certain household factors, such as income, education, and household size. Similarly, TISDELL \& WILSON (2003) reported that higher-income groups are more likely to pay an entrance fee compared to lowerincome groups, but education was insignificant in all regressions. Income was also found by (IASHA, et. al., 2015) as a significant variable which has positive relationship with WTP. Also, visitors who are advocates of nature conservation were more likely in favor of an entrance fee. KAMRI (2013) supporeds this view by reporting that visitors are more willing to pay if the aim for charging was to conserve the park. A Turkish study determined the value added to the region based on use types, changes, planning and management approaches (BELKAYALI et al., 2010). Those authors reported that income and education were significant factors. One of the interesting findings that resulted from the study was that people who were visiting the area around Goreme Historical National Park were more likely to be willing to pay an entrance fee compared to people who were not visiting the area.

\section{MATERIALS AND METHODS}

\section{Study objective and sample size}

The primary objective of the present study was to assess visitors' attitudes toward an entry fee at Lake Karagol. Sample size was determined by considering the number of annual visitors to Lake Karagol, and it was calculated according to the formula published by FINK (2002):

$\mathrm{n}=\frac{N}{\left(1+N * p^{2}\right)}$, where, $\mathrm{n}$ was the determined sample size, $\mathrm{N}$ was the population size, and $\mathrm{p}$ was the level of precision. Although, the sample size was estimated to be 96 at the $95 \%$ confidence level and with a $5 \%$ margin of error for a total visitor population size of approximately 14,000 , only 92 samples were collected.

\section{Distribution of questionnaires}

A pilot test was carried out with five people in order to understand whether or not the questions were clear and understandable for respondents. Using the feedback received, some questions were made clearer and some questions were reformulated during and after the pilot survey. In-person interviews were conducted on Sunday, August 22, 2015, at 12:00 and 16:00, and on Sunday, August 29, 2015, at 12:00 and 16:00. These specific times were chosen because they were peak visitor times at the lake. The response rate was $80 \%$. Each interview took approximately 20 minutes. The survey was conducted by five people. Figure 1 shows the home districts of the Lake Karagol visitors.

The questionnaire mostly consisted of closed-ended questions. First section of the interview asked perception questions about environmental concerns, such as protecting the environment, the idea of development not covering environment, and expectations about Lake Karagol. Preferences were measured on a five-point Likert scale: "strongly agree", "agree", "neutral", "disagree", and "strongly disagree". Following the perception questions, respondents were presented with a hypothetical scenario about uncontrolled overuse of the existing 


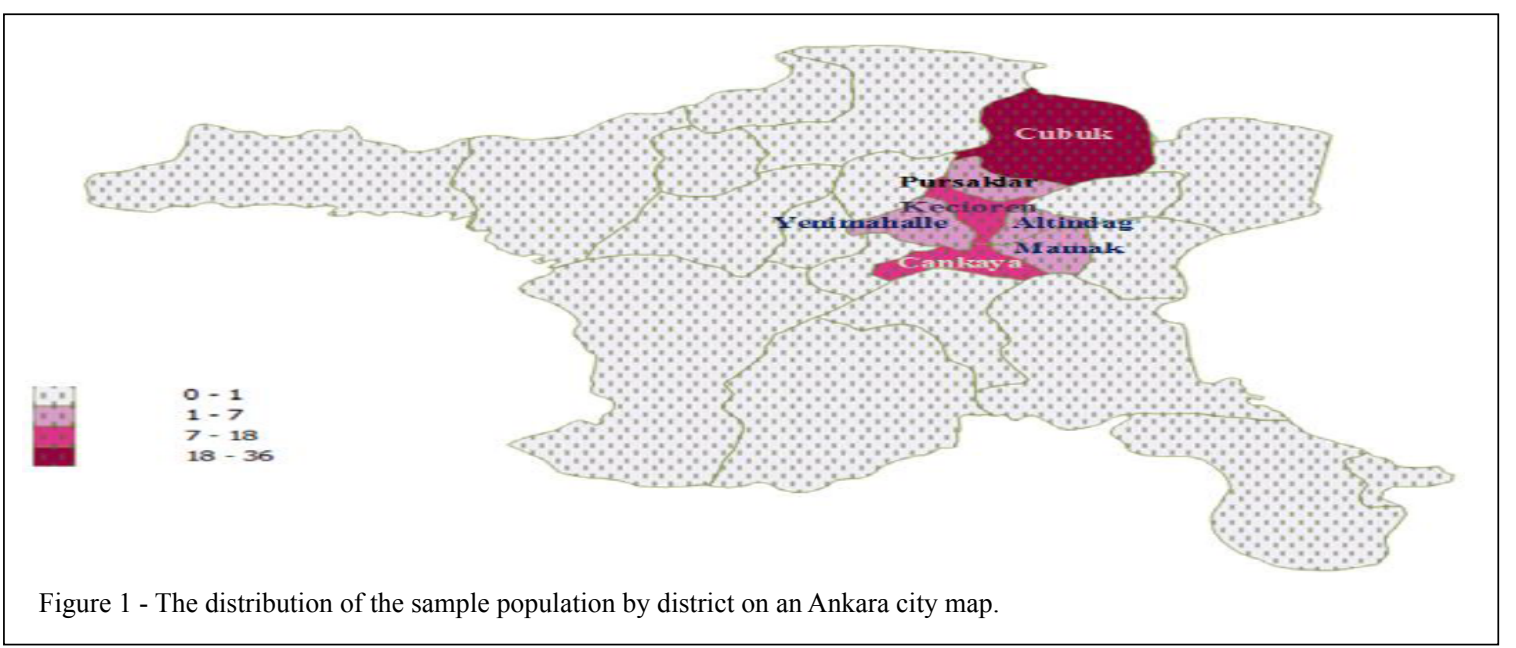

capacity, erosion risk, the most likely causes of pollution in the future at Lake Karagol, and about aquatic biota being under threat. Moreover, the scenario highlighted that the collected fee would be used for environmental protection and maintenance of the protected areas, such as Lake Karagol, by underlining the statement, "it is strongly recommended that you should consider your disposable income, environmental concerns, and possible positive and negative consequences of the entrance fee when making your decision." The WTP question was formulated as follows: "For the Lake Karagol, as a starting bid, would you be willing to pay USD 3.33 for entrance fee?" Double dichotomous questions were used in the survey. Respondents were first asked whether or not they would be willing to pay the starting bid. They could either answer in the affirmative (accept the bid) or in the negative (reject the starting bid). Those who responded to the starting bid positively were asked about continuously increasing bids up to USD 8.33; bids for the entry fee were increased in increments of USD 1.60. After USD 8.33 was reached, the respondents were asked to state the maximum amount they would be willing to pay. For people who rejected the starting bid, they were asked continuously decreasing bids until they were finally asked to tell what amount they would be willing to pay. Regardless of whether respondents gave an affirmative answer or a negative answer, they were asked to state why they would be willing or unwilling to pay. All answers were carefully noted. Finally, respondents were asked personal profile questions, including income, education, and age, in order to measure possible influences on WTP.

Regression models of the contingent valuation method Probitand logit analyses were mostly applied in binary-choice models. AMEMIYA (1981) stated that samples with heavier tails are more appropriate for logit models. Similarly, CAKMAKYAPAN and GOKTAS (2013) showed that a probit model is usually preferred for smaller sample sizes rather than a logit model, which is more appropriate for large samples. After considering the sample size, the best model to employ was the probit model.

Data were analyzed with the help of STATA/IC 12.0 software. The WTP amount was based on a probit model that included all WTP responses $(n=92)$.

\section{Probit model}

The Probit model is defined by WOOLDRIDGE (2006) as $\mathrm{Zn}=\mathrm{Xn} \beta+\mathrm{un}$, where $\beta$ is a vector of parameters, including the intercept term; $\mathrm{xn}$ is a vector of covariates; and $\mathrm{u}$ is the error term, which either has the standard logistic distribution or the standard normal distribution. In this case, $\mathrm{u}$ is symmetrically distributed around zero. $\mathrm{Zn}$ is the unobservable amount that respondents are willing to pay for the entry fee to Lake Karagol. WTPi is the observed dichotomous variable stating whether the individual pays or not. It can be defined as follows: $\mathrm{WTPn}=0$ if $\mathrm{WTPn}^{*} \leq 0 ; \mathrm{WTPn}=1$ if $\mathrm{WTPn}^{*}>0$.

As has been demonstrated by Woolrdige (2006), the main goal of the binary responses was to 
explain the effects of $\mathrm{x}$ on the response that followed the probability $\mathrm{P}(\mathrm{y}=1 \mid \mathrm{x})$.

$\mathrm{P}(\mathrm{WTP}=1 \mid \mathrm{x})=\mathrm{P}\left(\mathrm{WTPn}^{*}>0 \mid \mathrm{x}\right)=\mathrm{P}[\mathrm{e}>-(\beta 0+\mathrm{x} \beta \mid \mathrm{x}]$ $=1-\mathrm{G}[-(\beta 0+\mathrm{x} \beta 0]=\mathrm{G}(\beta 0+\mathrm{x} \beta)$

Direction of the effect of $\mathrm{xi}$ on $\mathrm{E}\left(\mathrm{WTP}^{*} \mid \mathrm{x}\right)=\beta 0+$ $\mathrm{x} \beta$ and on $\mathrm{E}(\mathrm{WTP} \mid \mathrm{x})=\mathrm{P}(\mathrm{y}=1 \mid \mathrm{x})=\mathrm{G}(\beta 0+\mathrm{x} \beta)$ are similar to each other.

It was not possible to apply ordinary least squares due to the nonlinear nature of $E(y \mid x)$. Therefore, maximum likelihood methods were used in order to estimate the limited dependent variable models. The maximum likelihood can be written as follows (WOOLDRIDGE, 2006): $f(\mathrm{WTP} \mid \mathrm{xi} ; \beta)=$ [G(xi $\beta)] y[1-G(x i \beta)] 1-y$, WTP-0,1.

It can easily be seen that when $\mathrm{y}=1$ results in $G(x, \beta)$, and when $y=0$ results in $1-G(x i \beta)$. Function of the log likelihood for observation is a function of the parameters and the data $(x i, y i) ; \operatorname{li}(\beta)$ $=\mathrm{WTPi} \log [\mathrm{G}(\mathrm{xi} \beta)]+(1-\mathrm{WTPi}) \log [1-\mathrm{G}(\mathrm{xi} \beta)]$.

\section{Lake Karagol}

Lake Karagol, which is located $74 \mathrm{~km}$ from Ankara, is in the northern part of Ankara province. It is a small barrier landslide lake. According to an article published in a local newspaper <http:// www.cubuksesi.com/?s=haber\&id $=2922>$. in 2014, water levels of the lake have declined by 1 meter, but there has been no research done to prove that statement. Total number of visitors is estimated to be approximately 14,000 people each year, according to the Municipal of Cubuk's records. In general, families gather together in groups to have picnics, particularly for a barbecue, and they sometimes even camp overnight. The total surface of the lake is 10 hectares (Figure 2).

In recent years, the park has made efforts of afforestation and regeneration of a wide spectrum of trees and shrubs. In addition, the restaurant that is located in the park is being renovated by the Great Ankara Municipality.

An entrance fee to Lake Karagol has not been applied for about ten years. No outdoor activities are organized at the lake. Lake Karagol was given the status of a protected area in 2011 by the Ministry of Forestry and Water Affairs.

\section{RESULTS AND DISCUSSION}

\section{Descriptive analysis of the data}

The sample had a mean age of 37.4 years, with respondents ranging from 18 to 64 years

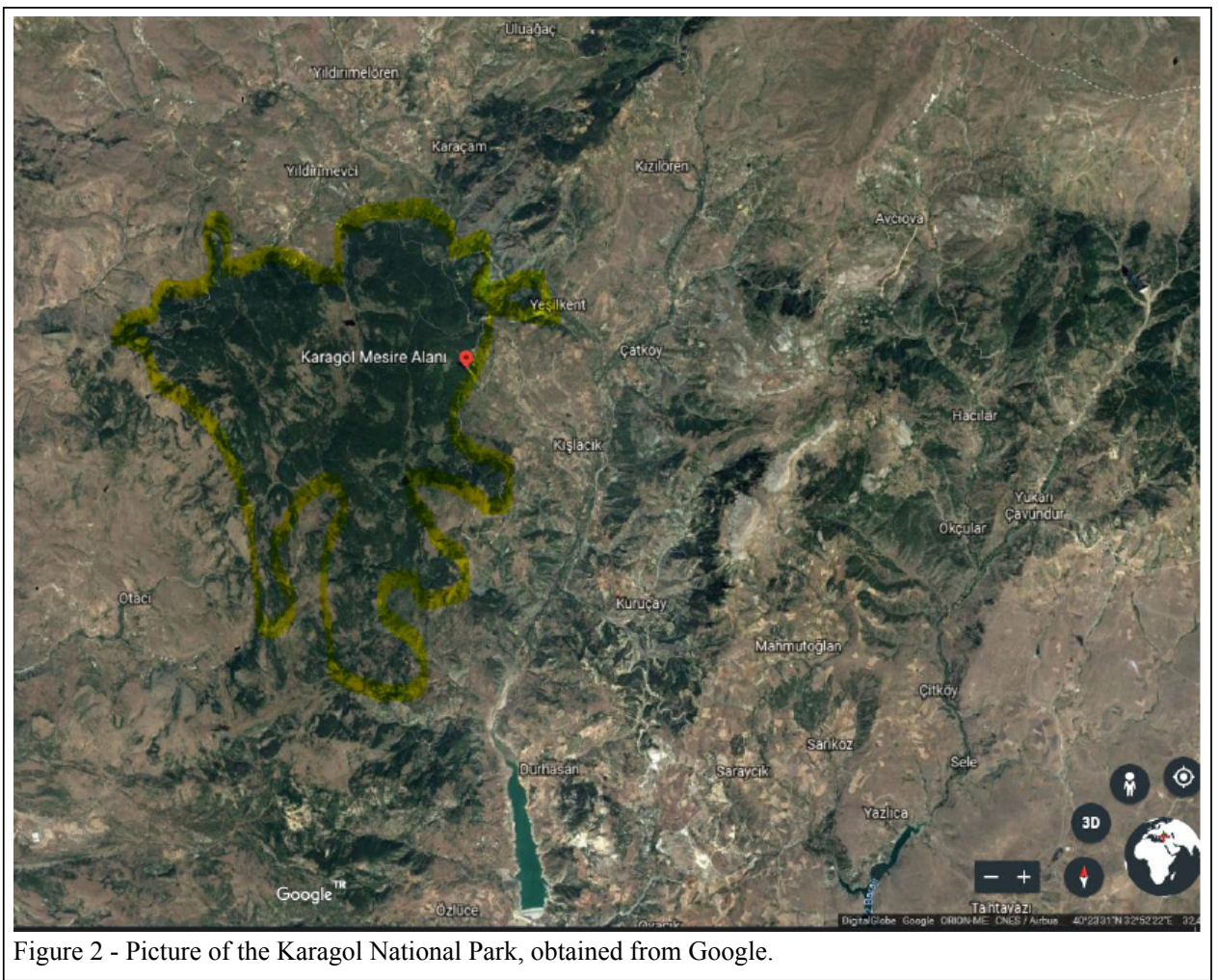

Ciência Rural, v.48, n.7, 2018. 
of age. Seventy percent of the sample consisted of male respondents. The mean household size was 3.62 members, and the range was 1 to 6 members. With respect to occupation, 47 (51.1\%) respondents classified themselves as engaged in the public sector, $21(22.8 \%)$ as engaged in the private sector, $6(6.5 \%)$ as retired or self-employed, and $5(5.4 \%)$ as students. Regarding education of respondents, 40 (63\%) persons had obtained a bachelor degree or higher, and $14(15.2 \%)$ had received a vocational school of higher education degree, 28 (30.4\%) reported having completed high school with no further education, and $10(10.8 \%)$ reported having completed primary and secondary school with no further education.

\section{Perceptions of the Lake}

A question was asked in order to measure the perception of visitors about the Lake. Twenty five $(27.1 \%)$ respondents strongly agreed and 25 $(27.2 \%)$ agreed. When respondents were asked if people should pay for protection and maintenance of protected areas and of the parks they visit, 22 (23.9\%) strongly agreed and $13(14.1 \%)$ agreed. More than $50 \%$ of respondents were in favor of a fee to be used for protection and maintenance. A similar result was reported by DRIVER (1984), indicating that fees collected to improve service offerings are favorably supported by users. However, HARRIS \& DRIVER (1987) acknowledged that fee supporters might counter the idea that fees could improve the quality of recreation.

When respondents were asked if they "would not mind if one hectare was used for other purposes", 54 (58.7\%) strongly agreed and 22 (23.9\%) disagreed. Respondents overwhelmingly showed lack of awareness for environmental sustainability.

With regard to the question, "I should not pay for the protected areas and parks that I do not even visit", 43 (46.7\%) strongly agreed and 17 (18.5\%) agreed. A similar stance comes from the previous question. Fifty three percent of the respondents said "yes" to an entry fee for the protected areas that they visit. This shows that "willingness to accept for an entrée fee" is far bigger than "willingness to pay" when considering that $14 \%$ of the respondents were willing to pay an entrance fee for Lake Karagol.

Of the respondents sampled, 73 (79.4\%)

thought that Lake Karagol was polluted. Younger respondents considered environmental problems to be more serious than older respondents. Respondents belonging to the 31-45 age groups were more willing to pay than other age groups, and $63(68.5 \%)$ considered themselves to be environmentalist. When asked "do you have barbecue when you visit Lake Karagol?", $84(91.3 \%)$ answered "yes" to the question. Having the chance to have barbecue is an important factor for people who visit Lake Karagol.

When respondents were asked about for what reason they visit Lake Karagol, 66 (71\%) picked up the choice of nature of Lake Karagol, other which generally refers to recreational facilities was picked up by 9 people $(9.7 \%)$, quiet atmosphere of Lake was chosen by $7(7.6 \%)$, closeness to city center was also picked up by 7 persons $(7.6 \%)$, no alternative place was picked up by 2 persons $(2.1 \%)$ and possibility to have barbecue in around Lake was $1.1 \%$ ( 1 person). Of the respondents who prefer to travel to long distances, 52 persons $(77.7 \%)$ indicated that they would like to see recreational facilities, such as a guesthouse, hotel, and shops; $66(71.4 \%)$ of the respondents lived in the district where Lake Karagol was located.

One question aimed to understand the priorities of the respondents who used public transportation-36 (39\%) respondents wanted to travel to Lake Karagol by bus, and $56(61 \%)$ respondents did not want to travel by bus. Generally, those wanting to come by bus had shorter distances to travel to visit. Approximately $70 \%$ of the respondents who had long distances to travel to visit indicated that they would be unwilling to come by bus.

When respondents were asked about their references for prioritizing new investment, $19.9 \%$ of the respondents indicated security measures and $17.4 \%$ referred to the development of infrastructure, including asphalt road and recreational facilities, such as guest houses or small shops. About 15.9\% of respondents suggested improvements to walking pathways, while $12.7 \%$ suggested the construction of restrooms. Suggestions to improve signposts, picnic tables and covers, and bicycle pathways were $7.6 \%$, $7.2 \%$, and $5.8 \%$, respectively.

\section{Willingness to pay}

Respondents were asked if they would be willing to pay a certain amount for the conservation and maintenance of the lake by establishing an entrance fee- $63 \%$ of the sample showed that they would be willing to pay, while $37 \%$ protested against the offered bid.

A large number of protest bids were recorded. Sixteen respondents $(53.33 \%)$ stated that there should be no entrance fee for the parks and protected areas. Thirteen respondents (more than $43 \%$ ) said protection and maintenance of the parks should be done by the government. 
As for the question that addressed the motivation behind a respondent's willingness to pay entrance fees, 28 respondents (approximately 46\%) indicated that they would like to protect the ecological balance of the environment, while 13 respondents $(21.3 \%)$ said they would spend more time at the lake if new investments were made using the collected entrance fees. The average WTP for an entrance fee was found to be about USD 0.22 for all observations when zero bids were included, and USD 4.42 when zero bids were excluded. In a similar study published by LEE et al (2013), the entrance fee for SunCheon Bay Ecological Park in Korea was estimated to be USD 3.00, and the fee might increase to about USD 4.00 if satisfaction levels can be guaranteed.

Respondents who had long distances to travel to get to Lake Karagol intended to pay more than those who had short distances to travel. A similar view was held by KAHNEMAN et al. (1986). As the distance from the respondents' homes to the site increased, the more the WTP price increased.

Econometric analysis: using a probit analysis to determine factors that influence WTP

As shown in table 1, respondents who had higher incomes demonstrated an increased probability $(19 \%)$ of being willing to pay. Respondents who indicated, "We do not have to invest in the environment so that people can benefit from current natural resources" was associated with an increase of $8 \%$ in the probability of WTP, those who are accepting to pay for protection and maintenance of the lake decreased the probability of WTP by $10 \%$, respondents who were in the $31-45$ age group increased the probability of WTP by $0.7 \%$, and respondents who worked for the public sector increased the probability of WTP by $4.4 \%$.
As pointed out by LINDBERG (1991), income, education, age, and working conditions had significant impacts on WTP in many studies. In the present study, we reported that all factors had an influence on WTP, with the exception of education.

Additionally, variables such as "exploiting the lake for different purposes", "pro-development", "people should pay for protection and maintenance", and "profession" were had significant impacts on the WTP probability. Particularly, exploiting the lake for different purposes decreased the probability of WTP. Despite the fact that a large number of respondents are in support of paying for protection and maintenance, they would be unwilling to pay the entry fee, which decreased the probability of WTP.

When Indians were asked a question measuring environmental sensitivity of visitors, $8.1 \%$ of the respondents strongly agreed and $23.5 \%$ agreed, which indicates that Turkish people favored paying for protected areas and parks that they do not even visit (HADKER et al., 1997).

Another important point was the distance that respondents had to travel to get to Lake Karagol. The longer the distance, the higher the accepted entrance price. As a matter of fact, our survey inferred that visitors who drove longer distances would be willing to pay more than those who drove shorter distances. The consideration that the number of visitors, particularly from shorter distances, could decline when charged with an entry fee. As stated by REYNISDOTTIR et al. (2008), a place people visit more frequently might have to charge less than other sites that people tend to visit less frequently.

Eighty-four respondents (91\%) said they would have a barbecue, while eight respondents (9\%) would not. One view expressed by MCCARVILLE et al. (1996) was that the number of visitors could decline

Table 1 - Probit model (dependent variable: willingness to pay).

\begin{tabular}{lcccc}
\hline Variable & Coefficient & Standard error & Marginal effect & Standard error \\
\hline Constant & -2.955678 & 1.293972 & & 0.06781 \\
Income & $0.6343294^{* * *}$ & 0.1424165 & $0.1944188^{* * *}$ & 0.20185 \\
Exploiting of Lake & -0.7061739 & 0.5299608 & -0.2496244 & 0.03184 \\
No investment for environment & $0.2658184^{* *}$ & 0.1062222 & $0.081472^{* *}$ & 0.0535 \\
\hline Education & 0.2107682 & 0.1786126 & 0.0645994 & 0.033 \\
Paying for protection and maintenance & $-0.3282717^{* * *}$ & 0.1127388 & $-0.1006136^{* * *}$ & 0.00466 \\
Age & $0.0257526^{*}$ & 0.0154592 & $0.0078931^{*}$ & 0.02355 \\
\hline Profession & $0.1424165^{*}$ & 0.0787767 & $0.0436499^{*}$ & \\
\hline
\end{tabular}

Probit regression; number of observations: 92; probability > chi2:0.0001; pseudo $\mathrm{R}^{2}: 0.2712$. 
after fees are introduced. Our study showed that only $15 \%$ of respondents did not protest the starting bias, while the rest of the sample overwhelmingly protested it. However, in subsequent bids, $63 \%$ of the protest bids yielded a positive response; this finding actually supports the view of MCCARVILLE et al. (1996). The majority of respondents were not in favor of a higher entry fee because they come with their families of at least three people. When they were asked "why you do not want to pay the first starting bid", it was generally indicated that it was too high if the size of the family was considered. Therefore, it seems that a fee of around USD 3.00 per person would not be satisfactory, and a sharp decline in the number of visitors would occur if that price was set. Instead, respondents intended to pay modest amounts for entry, with a mean price of USD 0.20 per person.

Considering about 14,000 visitors yearly, not excluding protest bids, an entrance price of USD 0.22 per person would yield a total of USD 3,080 per year. If protest bids were excluded from the estimations, this total amount would increase to USD 61,880 . However, the latter estimation would not be realistic because the number of visitors would be expected to decline sharply. Operation and maintenance costs of Lake Karagol were found to be USD 10,666.00, on the basis of contracts made by the Regional Directorate of Forestry and Water Affairs, who was the owner of Lake Karagol in previous years. The real cost of the lake has been undervalued by the respondents visiting Lake Karagol since the calculation made by the number of visitors and what amount they are willing to pay. The amount respondents would be willing to pay for the protection and maintenance of the park do not even meet the operation and maintenance costs of the Lake. However, the successful bidder who would intend to run a restaurant, in addition to charging an entry fee, can gain benefit in order to compensate for the operational costs.

\section{CONCLUSIONS}

The objective of this study was to assess visitors' attitudes toward an entry fee at Lake Karagol. "Contingent Valuation Method" is identified and properly applied to the case study. Estimating the economic value of natural resources that have no market value is one of the common methods used to determine value of goods in terms of social and environmental benefits. A survey was conducted to evaluate the level of visitors' interest in the protection of natural values and the willingness to pay to enter Lake Karagol.
The present study demonstrated that the willingness to accept would be higher than the willingness to pay for the maintenance and preservation costs of the parks from which they benefit. The amount people would be willing to pay to enter Lake Karagol would be insufficient to cover its expenses. Entrepreneurs intend to construct a restaurant or a shop in order to gain benefits from running the lake at the expense of damage to nature. Therefore, it can be concluded that parks without government incentives cannot survive. One of the drawbacks of the present study is that it estimates only stated preferences, and it does not include revealed preferences; a new study for estimating revealed preferences needs to be conducted for a health comparison.

\section{DECLARATION OF CONFLICT OF INTEREST}

The authors declare no conflict of interest. The founding sponsors had no role in the design of the study; in the collection, analyses, or interpretation of data; in the writing of the manuscript, and in the decision to publish the results

\section{REFERENCES}

ADAMS, R.M. et al. User fees and equity issues in public hunting expenditures: the case of ring-necked pheasant in Oregon. Land Economics, 65(4), 376-385, 1989.

AHMED, N. \& HUSSAIN, A. The Recreational Value of Rohtas Fort, Pakistan. Asia Pacific Journal of Tourism Research, 21(7), 782-794, 2016.

AMEMIYA, T. Qualitative response models: a survey. Journal of Economic Literature, 19(4), 1483-1536, 1981.

ARROW, K., et al.. Report of the NOAA panel on contingent valuation. Federal Register, January 15, vol. 58, no. 10, 46014614, 1993

BELKAYALI, N. et al.. Determination of economic value of Göreme Historical National Park via contingent valuation method. Scientific Research and Essays, 5(9), 934-940, 2010.

BRUNER, A., et al. Tourists' willingness to pay to visit Tanzania's National Parks: a contingent valuation study. Discussion Paper, No 9, 2015.

CAKMAKYAPAN, S. \& GOKTAS, A. A comparison of binary logit and probit models with a simulation study. Journal of Social and Economic Statistics, 2(1), 2013.

CUMMINGS, R.G., et al (Eds.) Valuing environmental goods: an assessment of the contingent valuation method: assessment of contingent valuation method. Rowman \& Littlefield, Savage, 1986.

DRIVER, B. Public responses to user fees at public recreation areas. Proceedings: Fees for Outdoor Recreation on Lands Open to the Public, 45-52, 1984. 
FINK, A. The Survey Handbook. 2nd edition. Sage Publications Inc., London, 2002.

HADKER, N., et al. Willingness-to-pay for Borivli National Park: evidence from a contingent valuation. Ecological Economics, 21(2), 105-122, 1997.

HANEMANN, W.M. Valuing the environment through contingent valuation. Journal of Economic Perspectives, 8(4), 19-43, 1994.

HARRIS, C.C., \& DRIVER, B.L. Recreation user fees: pros and cons. Journal of Forestry, 85(1), 25-29, 1987.

IASHA, A., et al. Estimating economic value for potential ecotourism resources in Puncak Lawang Park, Agam District, West Sumatera, Indonesia. Procedia Environmental Sciences 30, 326$331,2015$.

KAHNEMAN, D. et al. Fairness and the assumptions of economics. Journal of Business, 59(4), S285-S300, 1986.

LEE, W.S., et al. Willingness to pay for an ecological park experience. Asia Pacific Journal of Tourism Research, 18(3), 288-302, DOI: 10.1080/10941665.2011.652970, 2013

KAMRI, T. Willingness to pay for converstion of natural resources in the Gunung Gading National Park, Sarawak. Procedia-Social and Behavioral Sciences, Volume 101, 505-515, 2013.

LINDBERG, K. Policies for maximizing nature tourism's ecological and economic benefits. World Resources Institute, Washington, D.C., 22-37, 1991.

LINDBERG, K. Protected area visitor fees, overview. Cooperative Research Centre for Sustainable Tourism, Griffith University, Australia, 2001
REYNISDOTTIR, M. et al. Willingness to pay entrance fees to natural attractions: an Icelandic case study. Tourism Management, 29(6), 1076-1083, 2008.

MCCARVILLE, R.E., et al. The role of fairness in users' assessments of first-time fees for a public recreation service. Leisure Sciences: An Interdisciplinary Journal, 18(1), 61-76, doi: 10.1080/01490409609513272, 1996.

SCHULTZ, S., et al. Opportunities and limitations of contingent valuation surveys to determine national park entrance fees: evidence from Costa Rica. Environment and Development Economics, 3(1), 131-149, 1998.

SCHWARTZ, Z., \& LIN, L.-C. The impact of fees on visitation of national parks. Tourism Management, 27(6), 1386-1396, 2006.

STEVENS, T. el al. Pricing Policies for Public Day-use Outdoor Recreation Areas. Journal of Environmental Management, 28, 43-52, 1989.

PETERS, J. Sharing national park entrance fees: forging new partnerships in Madagascar. Society and Natural Resources, 11(5), 517-530, 1998.

TAO, Z., et al. Economic Valuation of Ecosystem Services in Heshui Watershed using Contingent Valuation Method. Procedia Environmental Sciences 13, 2445-2450, 2012.

TISDELL, C. \& WILSON, C. Attitudes to entry fees to national parks: Results and policy implications from a Queensland case study. Working papers on Economics, Ecology and the Environment, Working paper, No. 79, 2003.

WHITEHEAD, J \& BLOMQUIST, G. The use of contingent valuation in benefit-cost analysis. Preliminary Draft, 2001.

WOOLDRIDGE, J. Introductory Econometrics, fourth edition. South Western, 2006. 